\title{
ANALISIS PENGARUHGAYA KEPEMIMPINAN DOSEN \\ TERHADAP MOTIVASI BELAJAR MAHASISWA SEKOLAH TINGGI THEOLOGIA JAFFRAY MAKASSAR
}

\author{
Ivan Th. J. Weismann \\ ivanweismann@yahoo.com
}

\begin{abstract}
ABSTRAK
Penelitian bertujuan untuk menguji dan menganalisis pengaruh antara gaya kepemimpinan dosen terhadap motivasi belajar mahasiswa Sekolah Tinggi Theologia Jaffray Makassar.

Sampel yang digunakan dalam penelitian ini berjumlah 50 responden dari 391 mahasiswa. Teknik pengumpulan data ialah melalui angket. Metode analisis data yang digunakan adalah analisis regresi linier berganda.

Adapun hasil penelitian ini ialah Pada tingkat kematangan mahasiswa yang mampu dan mau (M4), tidak ada hubungan yang signifikan antara gaya kepemimpinan delegasi (G4) dosen terhadap motivasi belajar mahasiswa. Pada tingkat kematangan mahasiswa yang mampu tetapi tidak mau (M3), terdapat hubungan yang signifikan antara gaya kepemimpinan partisipasi (G3) dosen terhadap motivasi belajar mahasiswa. Pada tingkat kematangan mahasiswa (M2) yang tidak mampu tetapi mau, tidak ada hubungan yang signifikan antara gaya kepemimpinan konsultasi (G2) dosen terhadap motivasi belajar mahasiswa. Pada tingkat kematangan mahasiswa yang tidak mampu dan tidak mau (Ml), terdapat hubungan yang signifikan antara gaya kepemimpinan instruksi (Gl) dosen terhadap motivasi belajar mahasiswa.
\end{abstract}

Kata kunci: gaya kepemimpinan dosen, motivasi belajar mahasiswa 


\section{PENDAHULUAN}

\section{Latar Belakang Masalah}

Pendidikan merupakan usaha sadar dan terencana untuk mewujudkan suasana belajar dan proses pembelajaran agar peserta didik secara aktif mengembangkan potensi dirinya untuk memiliki kekuatan spiritual keagamaan, pengendalian diri, kepribadian, kecerdasan, akhlak mulia, serta keterampilan yang dibutuhkan bagi dirinya, masyarakat dan bangsa. Akan tetapi, kegiatan mendidik yang telah berlangsung selama ini kurang mendapat evaluasi yang cukup oleh para pelakunya, termasuk oleh para pendidik.

Pendidik dalam praktek mengajar hanya menyampaikan isi materi yang selalu sama kepada peserta didik meskipun individu peserta didiknya sudah berganti dan berbeda dalam hal kemampuan, bakat, minat, motivasi, dan kecenderungannya. Metode dan pendekatan yang dipakai untuk menyampaikan materi juga selalu sama tidak disesuaikan, yaitu dengan metode ceramah. Dengan demikian, kreativitas mendidik dan evaluasi kritis terhadap perilaku mendidik hampir tidak pernah dilakukan. Dosen mengajar menggunakan metode ceramah tanpa ada variasi. Proses pembelajaran hanya berlangsung satu arah, dosen bercerita panjang lebar dan mahasiswa mendengarkan. Pembelajaran tidak menuntut keaktifan mahasiswa untuk berperan dalam proses pembelajaran.

Metode ceramah, tanya jawab, dan menghafal dirasa tepat oleh dosen untuk menyampaikan materi pelajaran, sehingga dapat menjadikan mahasiswa mampu menghafal semua materi pelajaran. Akan tetapi penggunaan metode-metode tersebut ternyata justru membuat mahasiswa bosan dan tidak termotivasi untuk belajar, karena dalam metode tersebut hubungan utama antara dosen dan murid adalah berbicara. Dosen yang profesional harus memiliki pengetahuan yang luas dan mendalam mengenai bidang studi yang akan diajarkan kepada peserta didik dan metodologinya, memiliki pengetahuan yang fundamental tentang pendidikan, serta memiliki keterampilan yang vital bagi dirinya untuk memilih dan menggunakan berbagai strategi yang tepat dalam proses pembelajaran. ${ }^{1}$

Menanggapi masalah tersebut diharapkan adanya inovasi atau pembaharuan perlakuan dosen kepada mahasiswa dalam proses pembelajaran. Aspek kepemimpinan dosen dalam pembelajaran di kelas sangat penting karena dengan kemampuan memimpin yang tinggi dosen tidak hanya mampu mempengaruhi para mahasiswanya untuk belajar materi-materi ajar dengan baik melainkan

\footnotetext{
${ }^{1}$ Arif Rohman. Memahami Pendidikan dan Ilmu Pendidikan (Yogyakarta: LaksBang Mediatama Yogyakarta, 2009), 151
} 
mempengaruhi juga sikap dan perilaku mereka baik di perguruan tinggi maupun di luar perguruan tinggi.

Kemampuan dosen untuk mempengaruhi para siswa supaya melakukan pembelajaran dengan baik adalah suatu keharusan. Oleh karenanya, dosen profesional hendaklah selalu berupaya untuk meningkatkan kepemimpinannya dengan mengetahui tugas-tugas utama yang dilakukan pemimpin, fungsinya, dan keterampilan-keterampilan apa yang harus dimiliki untuk menjadi pemimpin yang baik. Dengan penguasaan hal-hal tersebut, diharapkan dsoen profesional dapat benar-benar memimpin mahasiswa mencapai tujuan-tujuan pendidikan.

Kepemimpinan pembelajaran lebih berorientasi pada:

1. Proses bagaimana kualitas pembelajaran mengalami peningkatan dari waktu ke waktu.

2. Menggerakkan mahasiswa mencapai kompetensi dasar semaksimal mungkin.

3. Penumbuhan motivasi internal belajar anak didik.

Ketiga orientasi tersebut tidak terjadi secara terpisah-pisah. Target akhir kepemimpinan pembelajaran adalah dosen mampu menumbuhkan motivasi (internal motivation) internal belajar anak didik, yang selanjutnya menjadi penggerak (drive) bagi anak didik untuk secara mandiri (self motivation) berupaya (dosen sekedar fasilitator, mediator, reseources linker, advisor) dalam mencapai kompetensi dasar pada dirinya secara maksimal sebagai bentuk kualitas pembelajarannya.

Dengan melihat dan memperhatikan uraian-uraian tersebut di atas, maka dilakukan penelitian dengan judul "Analisis Pengaruh Gaya Kepemimpinan Dosen Terhadap Motivasi Belajar Mahasiswa Sekolah Tinggi Theologia Jaffray Makassar.”

\section{Rumusan Masalah}

Untuk itu dalam memecahkan masalah tersebut perlu dikembangkan pertanyaan penelitian, antara lain sebagai berikut: Bagaimana pengaruh gaya kepemimpinan dosen terhadap motivasi belajar mahasiswa Sekolah Tinggi Theologia Jaffray Makassar?

\section{Tujuan Penelitian}

Adapun tujuan penelitian yang hendak dicapai adalah sebagai berikut: Untuk menguji dan menganalisis pengaruh gaya kepemimpinan dosen terhadap motivasi belajar mahasiswa Sekolah Tinggi Theologia Jaffray Makassar. 


\section{Kegunaan Penelitian}

Kegunaan penelitian ini ialah sebagai berikut:

Pertama, Kegunaan teoritis, yaitu memberikan tambahan referensi untuk mengembangkan ilmu pengetahuan khususnya bidang gaya kepemimpinan dosen dan motivasi belajar mahasiswa.

Kedua, Kegunaan praktis, yaitu diharapkan hasil penelitian dapat memberikan wawasan dan masukan kepada dosen dan mahasiswa tentang pengaruh dari gaya kepemimpinan terhadap motivasi belajar.

\section{Landasan Teori}

Gaya kepemimpinan

Gaya kepemimpinan yang digunakan dalam penelitian ini ialah gaya kepemimpinan Hersey-Blanchar yang diciptakan oleh Dr. Paul Hersey pengarang buku The Situasional Leader dan Ken Blanchard penulis buku The One-Minute Manager. Gaya kepemimpinan Hersey dan Blanchard, adalah kepemimpinan yang didasarkan atas hubungan saling mempengaruhi dan perilaku tugas.

Ashar Sunyoto Munandar menyebutkan empat dasar perilaku pemimpin atas dasar hubungan dan perilaku tugas yaitu, (l) perilaku tugas tinggi dan hubungan rendah, (2) perilaku tugas tinggi dan hubungan tinggi, (3) perilaku tugas rendah dan relasi tinggi, dan (4) perilaku tugas rendah dan relasi rendah. ${ }^{2}$ Menurut Miftah Thoha, empat gaya dasar kepemimpinan sebagai berikut: ${ }^{3}$

1. Perilaku pemimpin yang tinggi pengarahan dan rendah dukungan (Gl) dirujuk sebagai instruksi karena gaya ini dicirikan dengan komunikasi satu arah. Pemimpin memberikan batasan peranan pengikut dan memberitahu tentang apa, bagaimana, bilamana, dan dimana melaksanakan berbagai tugas. Inisiatif pemecahan masalah dan pembuatan keputusan semata-mata dilakukan oleh pemimpin. Pemecahan masalah dan keputusan diumumkan, dan pelaksanaannya diawasi secara ketat oleh pemimpin. Dalam gaya l (Gl), seorang pemimpin menunjukkan perilaku yang banyak memberikan pengarahan namun sedikit dukungan. Pemimpin ini memberikan instruksi yang spesifik tentang peranan dan tujuan bagi pengikutnya, dan secara ketat mengawasi pelaksanaan tugas.

\footnotetext{
2 Ashar Sunyoto Munandar, Psikologi Industri dan Organisasi (Jakarta:UI Devies, 2001), 190.

3 Mihtah Thoha. Kepemimpinan dalam Manajemen (Jakarta:PT Rajagrafindo, 2010), 66.
} 
2. Perilaku pemimpin yang tinggi pengarahan dan tinggi dukungan (G2) dirujuk sebagai konsultasi, karena dalam menggunakan gaya ini, pemimpin masih banyak memberikan pengarahan dan masih membuat hampir sama dengan keputusan, tetapi hal ini diikuti dengan meningkatkan komunikasi dua arah dan perilaku mendukung, dengan berusaha mendengar perasaan pengikut tentang keputusan yang dibuat, serta ide-ide dan saran-saran mereka. Meskipun dukungan ditingkatkan, pengendalian (control) atas pengambilan keputusan tetap pada pemimpin. Dalam gaya 2 (G2), pemimpin menunjukkan perilaku yang banyak mengarahkan dan banyak memberikan dukungan. Pemimpin dalam gaya seperti ini mau menjelaskan keputusan dan kebijaksanaan yang diambil dan mau menerima pendapat dari pengikut. Tetapi pemimpin dalam gaya ini masih tetap harus terus memberikan pengawasan dan pengarahan dalam penyelesaian tugas-tugas pengikut.

3. Perilaku pemimpin yang tinggi dukungan dan rendah pengarahan (G3) dirujuk sebagai partisipasi, karena posisi kontrol atas pemecahan masalah dan pembuatan keputusan dipegang secara bergantian. Dengan penggunaan gaya 3 ini, pemimpin dan pengikut saling tukar menukar ide dalam pemecahan masalah dan pembuatan keputusan. Komunikasi dua arah ditingkatkan, dan peranan pemimpin adalah secara aktif mendengar. Tanggung jawab pemecahan masalah dan pembuatan keputusan sebagian besar berada pada pihak pengikut. Hal ini sudah sewajarnya karena pengikut memiliki kemampuan untuk melaksanakan tugas. Pada gaya 3 (G3), perilaku pemimpin menekankan pada banyak memberikan dukungan namun sedikit dalam pengarahan. Dalam gaya seperti ini pemimpin menyusun keputusan-keputusan bersama-sama dengan para pengikut, dan mendukung usaha-usaha dalam menyelesaikan tugas.

4. Perilaku pemimpin yang rendah dukungan dan rendah pengarahan (G4) dirujuk sebagai delegasi, karena pemimpin mendiskusikan masalah bersama-sama dengan bawahan sehingga tercapai kesepakatan mengenai definisi masalah yang kemudian proses pembuatan keputusan didelegasikan secara keseluruhan kepada bawahan. Sekarang bawahan yang memiliki kontrol untuk memutuskan tentang bagaimanana cara pelaksanaan tugas. Pemimpin memberikan kesempatan yang luas bagi bawahan untuk melaksanakan pertunjukan mereka sendiri karena mereka memiliki kemampuan dan keyakinan untuk memikul tanggung jawab dalam pengarahan perilaku mereka sendiri. Adapun gaya 4 (G4), pemimpin memberikan sedikit dukungan dan sedikit pengarahan. 
5. Kepemimpinan situasional memandang kematangan sebagai kemampuan dan kemauan orang atau kelompok untuk memikul tanggungjawab mengarahkan perilaku mereka sendiri dalam situasi tertentu. Maka, perlu ditekankan kembali bahwa kematangan merupakan konsep yang berkaitan dengan tugas tertentu dan bergantung pada hal-hal yang ingin dicapai pemimpin.

\section{Kematangan Para Pengikut}

Kematangan pengikut menurut gaya kepemimpinan Hersey Blanchard terbagi ke dalam empat tingkat: ${ }^{4}$

1. Tingkat kematangan Ml (tidak mampu dan tidak ingin), tipe orang Ml ini memiliki tanggung jawab untuk melaksanakan sesuatu adalah tidak kompeten atau tidak memiliki keyakinan. Dengan demikian maka gaya kepemimpinan yang diterapkan pemimpin untuk memimpin bawahan adalah dengan gaya instruksi (Gl) yaitu dengan memberitahukan, menunjukkan, menginstruksikan secara spesifik. Oleh karena itu, gaya instruksi harus memberikan pengarahan yang jelas dan pengawasan ketat memiliki kemungkinan efektif yang paling tinggi.

2. Tingkat kematangan M2 (tidak mampu tetapi mau), tipe orang dengan M2 ini tidak mmpu tetapi berkeinginan untuk memikul tanggung jawab memiliki keyakinan tetapi kurang memiliki keterampilan. Dengan demikian maka gaya kepemimpinan yang diterapkan pemimpin untuk memimpin bawahan adalah dengan gaya konsultasi (G2) yang memberikan perilaku tinggi tugas dan tinggi hubungan.

3. Tingkat kematangan M3 (mampu tetapi tidak mau/ ragu-ragu). Orang pada tingkat perkembangan ini memiliki kemampuan tetapi tidak berkeinginan untuk melakukan tugas yang diberikan. Ketidakinginan mereka disebabkan karena kurangnya keyakinan. Dengan demikian, gaya yang dapat digunakan pemimpin untuk memimpin adalah gaya partisipasi (G3) dimana gaya ini memiliki tingkat keberhasilan yang tinggi untuk diterapkan bagi individu dengan tingkat kematangan seperti ini. Dalam pelaksanaannya pemimpin dapat memberikan perilaku yang tinggi hubungan dan rendah tugas.

4. Tingkat kematangan M4 (mampu dan mau). Orang dengan tingkat kematangan seperti ini adalah orang yang mampu dan mau, atau

\footnotetext{
${ }^{4}$ Hersey Blanchard, "The Hersey-Blanchard Situational Leadership Theory" diakses pada tanggal 15 Februari 2013; tersedia di http://www.mindtools.com/pages/article/newLDR_44.htm
} 
mempunyai keyakinan untuk memikul tanggungjawab. Dengan demikian gaya yang digunakan pemimpin untuk memimpin adalah gaya delegasi (G4). Dalam pelaksanaannya pemimpin dapat memberikan rendah hubungan dan rendah tugas.

Pemimpin harus mengetahui atau mengenal bawahan, entah itu kematangan kecakapannya ataupun kemauan/kesediaannya. Dengan mengenal tipe bawahan (kematangan dan kesediaan) maka seorang pemimpin akan dapat memakai gaya kepemimpinan yang sesuai. Bawahan sebagai orang yang ikut terlibat dalam proses pencapaian tujuan mempunyai sifat dan karakter yang berbeda-beda, karena itu menjadi penting untuk mempelajari kemampuan bawahan untuk memilih gaya kepemimpinan yang tepat.

Berdasarkan gaya kepemimpinan situasional yang telah dipaparkan, penulis mengembangkan instrumen dari teori Hersey dan Blanchard tersebut sebagai indikator instrumen penelitian ini, adapun indikatornya sebagai berikut.

Tabel 1. Indikator Gaya Kepemimpinan Hersey-Blanchard

\begin{tabular}{|c|c|c|}
\hline Variabel & Sub Variabel & Indikator \\
\hline \multirow{4}{*}{$\begin{array}{l}\text { Gay a } \\
\text { kepemimpin } \\
\text { an Hersey- } \\
\text { Blanchard }\end{array}$} & $\begin{array}{l}\text { 1. Gaya delegasi } \\
\text { Pada tingkat } \\
\text { kematangan M4 }\end{array}$ & $\begin{array}{l}\text { Rendah } \\
\text { hubungan } \\
\text { Rendah tugas }\end{array}$ \\
\hline & $\begin{array}{l}\text { 2. Gaya partisipasi } \\
\text { Pada tingkat } \\
\text { kematangan } \mathrm{M} 3\end{array}$ & $\begin{array}{l}\text { Tinggi } \\
\text { hubungan } \\
\text { Rendah tugas }\end{array}$ \\
\hline & $\begin{array}{l}\text { 3. Gaya konsultasi } \\
\text { Pada tingkat } \\
\text { kematangan } \mathrm{M} 2\end{array}$ & $\begin{array}{l}\text { Tinggi tugas } \\
\text { Tinggi } \\
\text { hubungan }\end{array}$ \\
\hline & $\begin{array}{l}\text { 4. Gaya instruksi } \\
\text { Pada tingkat } \\
\text { kematanganMl }\end{array}$ & $\begin{array}{l}\text { Tinggi tugas } \\
\text { Rendah } \\
\text { hubungan }\end{array}$ \\
\hline
\end{tabular}

\section{Pengertian Motivasi Belajar}

Motivasi memiliki peran yang penting dalam kegiatan belajar mengajar (KBM). Motivasi ini memiliki pengaruh yang besar terhadap proses belajar mahasiswa. Sebelum membahas lebih lanjut mengenai seberapa besar peran dari motivasi, terlebih dahulu 
dibahas mengenai pengertian motivasi.

Motivasi belajar pada mulanya adalah suatu kecenderungan alamiah dalam diri manusia, tetapi kemudian terbentuk sedemikian rupa dan secara berangsur-angsur, tidak hanya sekedar menjadi penyebab atau mediator belajar tetapi sebagai hasil belajar itu sendiri. Ngalim Purwanto, memperjelas bahwa motivasi adalah syarat mutlak untuk belajar. Di perguruan tinggi banyak mahasiswa yang malas, tidak menyenangkan, suka membolos, dan sebagainya. Hal ini berarti bahwa dosen tidak berhasil memberikan motivasi yang tepat untuk mendorong agar mahasiswa belajar dengan segenap tenaga dan pikirannya. ${ }^{5}$

Motivasi mempunyai empat pengaruh penting dalam pembelajaran, yang tiga diantaranya (a) motivasi memberikan semangat mahasiswa, mahasiswa menjadi lebih aktif, sibuk dan tertarik, motivasi menompang upayaupaya dan menjaga (belajar) mahasiswa tetap jalan, (b) motivasi mengarahkan dan mengendalikan tujuan, mahasiswa mengarah untuk melengkapi suatu tugas, mencapai tujuan yang diinginkan, (c) motivasi dapat menentukan kegiatan apa yang akan dilakukan dan bagaimana tugas-tugas itu akan dilakukan. Motivasi merupakan penentu prioritas untuk keberhasilan seseorang. Dikatakan penentu prioritas karena (a) motivasi merupakan motor penggerak dari setiap kebutuhan yang akan dipenuhi, (b) menentukan tujuan yang hendak dicapai, dan (c) menentukan perbuatan yang harus dilakukan.

\section{Indikator Motivasi Belajar}

Apabila seseorang telah mempunyai ciri-ciri atau indikator motivasi maka orang tersebut selalu memiliki motivasi yang cukup kuat. Kegiatan belajar mengajar akan berhasil baik, jika mahasiswa rajin mengerjakan tugas, terampil, dan mampu memecahkan berbagai masalah dan hambatan secara mandiri. Selain itu mahasiswa juga harus peka dan responsif terhadap masalah umum dan bagaiman cara memecahkannya. Mahasiswa yang telah termotivasi memiliki keinginan dan harapan untuk berhasil dan apabila mengalami kegagalan mereka akan berusaha keras untuk mencapai keberhasilan itu yang ditujukan dalam prestasi belajarnya. Dengan kata lain adanya usaha yang tekun dan terutama didasari adanya motivasi maka sesorang yang belajar akan melahirkan prestasi yang baik.

Menurut Hamzah B. Uno, indikator motivasi belajar dapat diklasifikasikan sebagai berikut: (1) adanya hasrat dan keinginan berhasil; (2) adanya dorongan dan kebutuhan dalam belajar; (3) adanya

\footnotetext{
${ }^{5}$ Ngalim Purwanto. Psikologi Pendidikan. Jakarta:PT Remaja Rosdakarya, 1990, 60.
} 
harapan dan cita-cita masa depan; (4) adanya penghargaan dalam belajar; (5) adanya kegiatan yang menarik dalam belajar; (6) adanya lingkungan belajar yang kondusif, sehingga memungkinkan seseorang mahasiswa dapat belajar dengan baik. Mahasiswa yang memiliki motivasi belajar kuat karena adanya hasrat dan keinginan untuk berhasil. Keberhasilan tersebut dapat dicapai dengan dorongan dan kebutuhan dalam belajar dan lingkungan belajar yang kondusif. ${ }^{6}$

Menurut Sardiman, indikator motivasi belajar meliputi tekun menghadapi tugas, ulet menghadapi kesulitan, menunjukkan minat terhadap bermacam-macam masalah, lebih senang bekerja mandiri, cepat bosan pada tugas-tugas yang rutin, dapat mempertahankan pendapatnya, tidak mudah melepaskan hal yang diyakini, senang mencari dan memecahkan masalah. ${ }^{7}$

Menurut Sugihartono, motivasi yang tinggi dapat ditemukan dalam sifat perilaku mahasiswa dengan indikator antara lain yaitu adanya kualitas keterlibatan mahasiswa dalam belajar yang sangat tinggi, adanya perasaan dan keterlibatan afektif mahasiswa yang tinggi dalam belajar, adanya upaya mahasiswa untuk senantiasa memelihara atau menjaga agar senantiasa memiliki motivasi belajar tinggi. ${ }^{8}$

\section{Hubungan Gaya Kepemimpinan Terhadap Motivasi Belajar}

Kepemimpinan dosen yang diperlihatkan dan diterapkan ke dalam suatu gaya kepemimpinan merupakan salah satu faktor dalam peningkatan motivasi belajar mahasiswa. Untuk itu dosen perlu memikirkan dan memperlihatkan gaya kepemimpinan yang tepat dalam penerapannya.

Gaya kepemimpinan ialah pola perilaku dan strategi yang disukai dan sering diterapkan dosen, dengan menyatukan tujuan perguruan tinggi dengan tujuan mahaiswa, dalam rangka mencapai tujuan atau sasaran yang telah menjadi komitmen bersama.

Berdasarkan uraian tersebut diatas maka peneliti mengajukan kerangka pemikiran yang menjelaskan bahwa gaya kepemimpinan dosen (X) berpengaruh kuat terhadap motivasi belajar mahasiswa (Y).

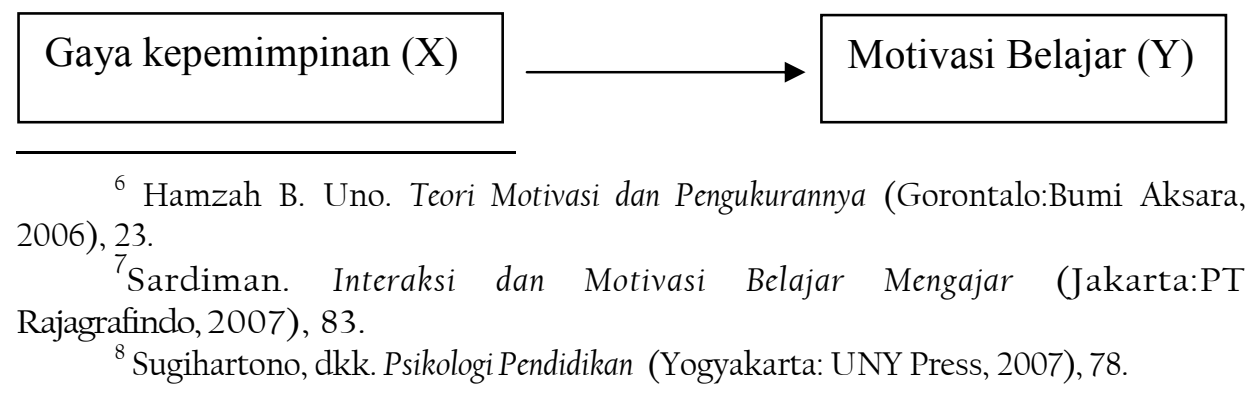




\section{METODE PENELITIAN}

\section{Populasi dan Sampel}

Populasi dalam penelitian ini adalah seluruh mahasiswa Sl Sekolah Tinggi Theologia Jaffray Makassar berjumlah 391 orang. Peneliti menetapkan sampel sebesar 50 responden dari popuasi sebesar 391, yang diambil dari mahasiswa tahun pertama.

\section{Teknik Pengumpulan Data}

Metode Pengumpulan Data penelitian ini terdiri dari dua kuesioner yaitu: Kuesioner tentang variabel gaya kepemimpinan dan motivasi belajar. Pertanyaan-pertanyaan dalam kuesioner dibuat dengan skala ordinal atau sering disebut skala likert.

\section{Teknik Analisis Data}

Analisis Regresi Linier Berganda. Adapun persamaan regresi linier bergandanya adalah sebagai berikut : $\mathrm{Y}=\mathrm{a}+\mathrm{blXl}+\mathrm{b} 2 \mathrm{X} 2+\mathrm{b} 3 \mathrm{X} 3+\mathrm{e} \&$.. Dimana:

$$
\begin{aligned}
& \text { Y = Variabel dependen (Gaya Kepemimpinan) } \\
& \text { X = Variabel independen (Motivasi Belajar) } \\
& \text { a = Konstanta } \\
& \text { bl,b2 = Koefisien regresi } \\
& \text { e = Variabel lain yang tidak diteliti }
\end{aligned}
$$

\section{HASIL DAN ANALISA PEMBAHASAN}

Pengaruh gaya kepemimpinan delegasi (G4) dosen (rendah hubungan dan rendah tugas) dengan tingkat kematangan M4 mahasiswa (mampu dan mau) terhadap motivasi belajar mahasiswa

Model Summary ${ }^{\mathrm{b}}$

\begin{tabular}{|l|c|l|l|l|}
\hline Model & $\mathrm{R}$ & $\begin{array}{l}\mathrm{R} \\
\text { Square }\end{array}$ & $\begin{array}{l}\text { Adjusted } \\
\text { R Square }\end{array}$ & $\begin{array}{l}\text { Std. Error of the } \\
\text { Estimate }\end{array}$ \\
\hline $\mathrm{l}$ &, $156^{\mathrm{a}}$ &, 024 &,- 017 & 9,236 \\
\hline
\end{tabular}
a. Predictors: (Constant), G4b, G4a
b. Dependent Variable: Mo

\section{Analisis Korelasi (r)}

Nilai koefisien korelasi (r) antara gaya kepemimpinan delegasi 
dosen dengan motivasi belajar seperti terlihat pada tabel di atas adalah 0,156. Angka ini menunjukkan bahwa terdapat hubungan yang positif dan sangat signifikan antara gaya kepemimpinan delegasi dosen dengan tingkat kematangan M4 mahasiswa terhadap motivasi belajar mahasiswa. Artinya jika gaya kepemimpinan dosen semakin baik, maka motivai belajar mahasiswa juga akan meningkat

\section{Analisis Koefisien Determinasi $\left(\mathrm{r}^{2}\right)$}

Nilai koefisien determinasi $\left(\mathrm{r}^{2}\right)$ terlihat pada kolom $\mathrm{R}$ square dalam tabel yaitu 0,024 atau jika dijadikan persen adalah 2,4\%. Ini berarti bahwa variabel bebas gaya kepemimpinan delegasi dosen dengan tingkat kematangan M4 mahasiswa secara parsial dapat menjelaskan perubahan variabel terikat motivasi belajar mahasiswa sebesar 2,4\%. Angka tersebut juga dapat diartikan bahwa perubahan gaya kepemimpinan delegasi dosen dengan tingkat kematangan M4 mahasiswa akan memberi kontribusi positif terhadap motivasi belajar mahasiswa, sedangkan 87,6\% lagi dipengaruhi oleh faktor lain yang tidak termasuk dalam perhitungan ini.

ANOVA $^{\text {b }}$

\begin{tabular}{|ll|l|l|l|c|c|}
\hline \multicolumn{2}{|c|}{ Model } & $\begin{array}{l}\text { Sum of } \\
\text { Squares }\end{array}$ & df & $\begin{array}{c}\text { Mean } \\
\text { Square }\end{array}$ & F & Sig. \\
\hline 1 & Regression & 99,399 & 2 & 49,700 &, 583 &, $562^{\mathrm{a}}$ \\
& Residual & 4009,421 & 47 & 85,307 & & \\
& Total & 4108,820 & 49 & & & \\
\hline
\end{tabular}

a. Predictors: (Constant), G4b, G4a

b. Dependent Variable: Mo

\begin{tabular}{|cc|l|l|l|l|l|}
\hline \multirow{2}{*}{ Model } & \multicolumn{2}{|l|}{$\begin{array}{l}\text { Unstandardized } \\
\text { Coefficients }\end{array}$} & $\begin{array}{l}\text { Standardized } \\
\text { Coefficients }\end{array}$ & \multirow{2}{*}{$t$} & \multirow{2}{*}{ Sig. } \\
\cline { 3 - 5 } & B & Std. Error & Beta & & \\
\hline 1 & (Constant) & 44,411 & 12,815 & & 3,466 &, 001 \\
& G4a & $-1,226$ & 1,169 &,- 151 & $-1,049$ &, 300 \\
& G4b &, 156 &, 737 &, 031 &, 212 &, 833 \\
\hline
\end{tabular}

a. Dependent Variable: Mo

\section{Uji Hipotesis (Uji-t)}

Dari hasil pengujian hipoteis diperoleh nilai $t$ hitung $G 4 a$ (kepemimpinan delegasi dengan hubungan yang rendah $=1,049$. Jika dibandingkan dengan nilai t tabel pada level signifikan 5\% $(\alpha=0,05)$ dengan degree of freedom $(\mathrm{df})=47$ adalah 2,021. Jadi $t$ hitung $<t$ tabel, berarti Ho diterima dan Ha ditolak. Artinya tidak ada hubungan yang 
signifikan antara gaya kepemimpinan delegasi dosen dengan hubungan yang rendah pada tingkat kematangan mahasiswa yang mampu dan mau terhadap motivasi belajar mahasiswa.

Nilai t hitung G4b (kepemimpinan delegasi dengan tugas yang rendah $=0,212$. Jika dibandingkan dengan nilai $t$ tabel pada level signifikan $5 \%(\alpha=0,05)$ dengan degree of freedom $(\mathrm{df})=47$ adalah 2,021. Jadi t hitung < $\mathrm{t}$ tabel, berarti Ho diterima dan Ha ditolak. Artinya tidak ada hubungan yang signifikan antara gaya kepemimpinan delegasi dosen dengan tugas yang rendah pada tingkat kematangan M4 mahasiswa yang mampu dan mau terhadap motivasi belajar mahasiswa.

\section{Analisis Regresi Berganda}

Berdasarkan hasil perhitungan dapat disusun persamaaan regresi seagai berikut:

$\mathrm{Y}=44,411+(-1,226) \mathrm{Xl}+0,156 \mathrm{X} 2$

Dari persamaan di atas diketahui konstanta regresi 44,4ll, ini berarti pada saat variabel gaya kepemimpinan bernilai 0, motivasi belajar mahasiswa memiliki nilai 44,4ll. Sedangkan koefisien regresi variabel Xl (hubungan yang rendah) bernilai negatif 1,226 menunukkan bahwa variabel gaya kepemimpinan delegasi dengan hubungan yang rendah pada tingkat kematangan M4 mahaiswa berpengaruh negatif terhadap motivasi belajar mahasiswa, dimana setiap kenaikan satu satuan variabel kpemimpinan delegasi dosen dengan hubungan yang rendah pada tingkat kematangan M4 mahasiswa akan menurunkan motivasi belajar mahasiswa sebesar 1,226.

Koefisien regresi variabel X2 (tugas yang rendah) bernilai positif 0,156 menunukkan bahwa variabel gaya kepemimpinan delegasi dengan tugas yang rendah pada tingkat kematangan M4 mahaiswa berpengaruh positif terhadap motivasi belajar mahasiswa, dimana setiap kenaikan satu satuan variabel kepemimpinan delegasi dosen dengan tugas yang rendah pada tingkat kematangan M4 mahasiswa akan menaikkan motivasi belajar mahasiswa sebesar 0,156.

Pengaruh gaya kepemimpinan partisipasi (G3) dosen (tinggi hubungan dan rendah tugas) dengan tingkat kematangan M3 mahasiswa (mampu tetapi tidak mau karena kurang yakin) terhadap motivasi belajar mahasiswa

Model Summary
\begin{tabular}{|l|c|l|l|l|}
\hline Model & R & R Square & $\begin{array}{l}\text { Adjusted } \\
\text { Square }\end{array}$ & $\begin{array}{l}\text { Std. Error of } \\
\text { the Estimate }\end{array}$ \\
\hline 1 &, $447^{\mathrm{a}}$ &, 200 &, 166 & 8,363 \\
\hline
\end{tabular}

a. Predictors: (Constant), G3b, G3a 


\section{Analisis Korelasi (r)}

Nilai koefisien korelasi (r) antara gaya kepemimpinan partisipasi dosen dengan motivasi belajar seperti terlihat pada tabel di atas adalah 0,447 . Angka ini menunjukkan bahwa terdapat hubungan yang positif dan sangat signifikan antara gaya kepemimpinan delegasi dosen dengan tingkat kematangan M3 mahasiswa terhadap motivasi belajar mahasiswa. Artinya jika gaya kepemimpinan dosen semakin baik, maka motivai belajar mahasiswa juga akan meningkat

\section{Analisis Koefisien Determinasi $\left(\mathrm{r}^{2}\right)$}

Nilai koefisien determinasi $\left(\mathrm{r}^{2}\right)$ terlihat pada kolom $\mathrm{R}$ square dalam tabel yaitu 0,200 atau jika dijadikan persen adalah 20\%. Ini berarti bahwa variabel bebas gaya kepemimpinan partisipasi dosen dengan tingkat kematangan M3 mahasiswa secara parsial dapat menjelaskan perubahan variabel terikat motivasi belajar mahasiswa sebesar 20\%. Angka tersebut juga dapat diartikan bahwa perubahan gaya kepemimpinan partisipasi dosen dengan tingkat kematangan M3 mahasiswa akan memberi kontribusi positif terhadap motivasi belajar mahasiswa, sedangkan 80\% lagi dipengaruhi oleh faktor lain yang tidak termasuk dalam perhitungan ini.

ANOVA $^{\mathrm{b}}$
\begin{tabular}{|c|c|c|c|l|c|c|}
\hline \multicolumn{1}{|c|}{ Model } & $\begin{array}{c}\text { Sum of } \\
\text { Squares }\end{array}$ & df & Mean Square & F & Sig. \\
\hline 1 & Regression & 821,446 & 2 & 410,723 & 5,872 &, $005^{\mathrm{a}}$ \\
& Residual & 3287,374 & 47 & 69,944 & & \\
& Total & 4108,820 & 49 & & & \\
\hline
\end{tabular}

a. Predictors: (Constant), G3b, G3a

b. Dependent Variable: Mo

\section{Coefficients $^{\mathrm{a}}$}

\begin{tabular}{|cl|l|l|l|l|l|}
\hline \multirow{2}{*}{ Model } & \multicolumn{2}{|l|}{$\begin{array}{l}\text { Unstandardized } \\
\text { Coefficients }\end{array}$} & $\begin{array}{l}\text { Standardized } \\
\text { Coefficients }\end{array}$ & \multirow{2}{*}{$\mathrm{t}$} & \multirow{2}{*}{ Sig. } \\
\cline { 3 - 5 } & $\mathrm{B}$ & Std. Error & Beta & & \\
\hline \multirow{2}{*}{$\mathrm{l}$} & (Constant) & 18,265 & 6,536 & & 2,794 &, 008 \\
& G3a & 1,249 &, 448 &, 385 & 2,788 &, 008 \\
& G3b &, 376 &, 388 &, 134 &, 968 &, 338 \\
\hline
\end{tabular}

a. Dependent Variable: Mo 


\section{Uji Hipotesis (Uji-t)}

Dari hasil pengujian hipoteis diperoleh nilai $t$ hitung $G 3 a$ (kepemimpinan partisipasi dengan hubungan yang tinggi $=2,788$. Jika dibandingkan dengan nilai $t$ tabel pada level signifikan 5\% $(\alpha=0,05)$ dengan degree of freedom $(\mathrm{df})=47$ adalah 2,021. Jadi $t$ hitung $>t$ tabel, berarti Ho ditolak dan Ha diterima. Artinya terdapat hubungan yang signifikan antara gaya kepemimpinan partisipasi dosen dengan hubungan yang tinggi pada tingkat kematangan mahasiswa yang mampu tetapi tidak mau terhadap motivasi belajar mahasiswa.

Nilai t hitung G3b (kepemimpinan partisipasi dengan tugas yang rendah $=0,968$. Jika dibandingkan dengan nilai $t$ tabel pada level signifikan $5 \%(\alpha=0,05)$ dengan degree of freedom $(\mathrm{df})=47$ adalah 2,021. Jadi $\mathrm{t}$ hitung < $\mathrm{t}$ tabel, berarti Ho diterima dan Ha ditolak. Artinya tidak ada hubungan yang signifikan antara gaya kepemimpinan partisipasi dosen dengan tugas yang rendah pada tingkat kematangan M3 mahasiswa yang mampu tetapi tidak mau terhadap motivasi belajar mahasiswa.

\section{Analisis Regresi Berganda}

Berdasarkan hasil perhitungan dapat disusun persamaaan regresi seagai berikut:

$\mathrm{Y}=18,265+1,249 \mathrm{Xl}+0,376 \mathrm{X} 2$

Dari persamaan di atas diketahui konstanta regresi 18,265, ini berarti pada saat variabel gaya kepemimpinan bernilai 0 , motivasi belajar mahasiswa memiliki nilai 18,265. Sedangkan koefisien regresi variabel Xl (hubungan yang tinggi) bernilai positif 1,249 menunukkan bahwa variabel gaya kepemimpinan partisipasi dengan hubungan yang tinggi pada tingkat kematangan M3 mahaiswa berpengaruh positif terhadap motivasi belajar mahasiswa, dimana setiap kenaikan satu satuan variabel kepemimpinan partisipasi dosen dengan hubungan yang tinggi pada tingkat kematangan M3 mahasiswa akan menaikkan motivasi belajar mahasiswa sebesar 1,249.

Koefisien regresi variabel X2 (tugas yang rendah) bernilai positif 0,376 menunukkan bahwa variabel gaya kepemimpinan partisipasi dengan tugas yang rendah pada tingkat kematangan M4 mahaiswa berpengaruh positif terhadap motivasi belajar mahasiswa, dimana setiap kenaikan satu satuan variabel kepemimpinan partisipasi dosen dengan tugas yang rendah pada tingkat kematangan M3 mahasiswa akan menaikkan motivasi belajar mahasiswa sebesar 0,376.

Pengaruh gaya kepemimpinan konsultasi (G2) dosen (tinggi hubungan dan tinggi tugas) dengan tingkat kematangan M2 mahasiswa (tidak mampu tetapi mau) terhadap motivasi belajar mahasiswa 
Model Summary ${ }^{\mathrm{b}}$

\begin{tabular}{|l|c|l|l|l|}
\hline Model & $\mathrm{R}$ & R Square & $\begin{array}{l}\text { Adjusted R } \\
\text { Square }\end{array}$ & $\begin{array}{l}\text { Std. Error of } \\
\text { the Estimate }\end{array}$ \\
\hline 1 &, $113^{\mathrm{a}}$ &, 013 &,- 029 & 9,290 \\
\hline
\end{tabular}

a. Predictors: (Constant), G2b, G2a

b. Dependent Variable: Mo

\section{Analisis Korelasi (r)}

Nilai koefisien korelasi (r) antara gaya kepemimpinan konsultasi dosen dengan motivasi belajar seperti terlihat pada tabel di atas adalah 0,113. Angka ini menunjukkan bahwa terdapat hubungan yang positif dan sangat signifikan antara gaya kepemimpinan konsultasi dosen dengan tingkat kematangan M2 mahasiswa terhadap motivasi belajar mahasiswa. Artinya jika gaya kepemimpinan dosen semakin baik, maka motivai belajar mahasiswa juga akan meningkat

\section{Analisis Koefisien Determinasi $\left(\mathrm{r}^{2}\right)$}

Nilai koefisien determinasi $\left(\mathrm{r}^{2}\right)$ terlihat pada kolom $\mathrm{R}$ square dalam tabel yaitu 0,013 atau jika dijadikan persen adalah $1,3 \%$. Ini berarti bahwa variabel bebas gaya kepemimpinan konsultasi dosen dengan tingkat kematangan M2 mahasiswa secara parsial dapat menjelaskan perubahan variabel terikat motivasi belajar mahasiswa sebesar 1,3\%. Angka tersebut juga dapat diartikan bahwa perubahan gaya kepemimpinan konsultasi dosen dengan tingkat kematangan M2 mahasiswa akan memberi kontribusi positif terhadap motivasi belajar mahasiswa, sedangkan 98,7\% lagi dipengaruhi oleh faktor lain yang tidak termasuk dalam perhitungan ini.

ANOVA $^{\text {b }}$
\begin{tabular}{|c|l|l|l|l|l|l|}
\hline \multicolumn{2}{|c|}{ Model } & \multicolumn{1}{|c|}{$\begin{array}{c}\text { Sum of } \\
\text { Squares }\end{array}$} & df & Mean Square & F & Sig. \\
\hline 1 & Regression & 52,539 & 2 & 26,269 &, 304 &, $739^{\mathrm{a}}$ \\
& Residual & 4056,281 & 47 & 86,304 & & \\
& Total & 4108,820 & 49 & & & \\
\hline
\end{tabular}

a. Predictors: (Constant), G2b, G2a

b. Dependent Variable: Mo

\section{Coefficients $^{\mathrm{a}}$}

\begin{tabular}{|c|c|c|c|c|c|}
\hline \multirow{2}{*}{ Model } & \multicolumn{2}{|c|}{$\begin{array}{c}\text { Unstandardized } \\
\text { Coefficients }\end{array}$} & $\begin{array}{c}\text { Standardized } \\
\text { Coefficients }\end{array}$ & \multirow{2}{*}{$\mathrm{t}$} & Sig. \\
\cline { 2 - 4 } & $\mathrm{B}$ & Std. Error & Beta & \\
\hline
\end{tabular}




\begin{tabular}{|ll|l|l|l|l|l|}
\hline 1 & (Constant) & 32,667 & 10,086 & & 3,239 &, 002 \\
& G2a &, 144 & 1,353 &, 016 &, 106 &, 916 \\
& G2b &, 384 &, 546 &, 107 &, 704 &, 485 \\
\hline
\end{tabular}

a. Dependent Variable: Mo

\section{Uji Hipotesis (Uji-t)}

Dari hasil pengujian hipoteis diperoleh nilai $t$ hitung G2a (kepemimpinan konsultasi dengan tugas yang tinggi $=0,106$. Jika dibandingkan dengan nilai t tabel pada level signifikan 5\% $(\alpha=0,05)$ dengan degree of freedom $(\mathrm{df})=47$ adalah 2,021. Jadi t hitung < $t$ tabel, berarti Ho diterima dan Ha ditolak. Artinya tidak ada hubungan yang signifikan antara gaya kepemimpinan konsultasi dosen dengan tugas yang tinggi pada tingkat kematangan mahasiswa yang tidak mampu tetapi mau terhadap motivasi belajar mahasiswa.

Nilai t hitung G2b (kepemimpinan konsultasi dengan hubungan yang tinggi $=0,704$. Jika dibandingkan dengan nilai $t$ tabel pada level signifikan $5 \%(\alpha=0,05)$ dengan degree of freedom $(\mathrm{df})=47$ adalah 2,021. Jadi thitung < $t$ tabel, berarti Ho diterima dan Ha ditolak. Artinya tidak ada hubungan yang signifikan antara gaya kepemimpinan konsultasi dosen dengan hubungan yang tinggi pada tingkat kematangan M2 mahasiswa yang tidak mampu tetapi mau terhadap motivasi belajar mahasiswa.

\section{Analisis Regresi Berganda}

Berdasarkan hasil perhitungan dapat disusun persamaaan regresi seagai berikut:

$\mathrm{Y}=32,667+0,144 \mathrm{Xl}+0,384 \mathrm{X} 2$

Dari persamaan di atas diketahui konstanta regresi 32,667, ini berarti pada saat variabel gaya kepemimpinan bernilai 0 , motivasi belajar mahasiswa memiliki nilai 32,667. Sedangkan koefisien regresi variabel Xl (tugas yang tinggi) bernilai positif 0,144 menunukkan bahwa variabel gaya kepemimpinan konsultasi dengan tugas yang tinggi pada tingkat kematangan M2 mahaiswa berpengaruh positif terhadap motivasi belajar mahasiswa, dimana setiap kenaikan satu satuan variabel kepemimpinan konsultasi dosen dengan tugas yang tinggi pada tingkat kematangan M2 mahasiswa akan menaikkan motivasi belajar mahasiswa sebesar 0,144.

Koefisien regresi variabel X2 (hubungan yang tinggi) bernilai positif 0,384 menunjukkan bahwa variabel gaya kepemimpinan konsultasi dengan hubungan yang tinggi pada tingkat kematangan M2 mahaiswa berpengaruh positif terhadap motivasi belajar mahasiswa, dimana setiap kenaikan satu satuan variabel kepemimpinan konsultasi dosen dengan hubungan yang tinggi tingkat kematangan M2 mahasiswa akan menaikkan motivasi belajar mahasiswa sebesar 0,384. 
Pengaruh gaya kepemimpinan instruksi (Gl) dosen (rendah hubungan dan tinggi tugas) dengan tingkat kematangan Ml mahasiswa (tidak mampu dan tidak mau) terhadap motivasi belajar mahasiswa

Model Summary ${ }^{b}$

\begin{tabular}{|l|c|l|l|l|}
\hline Model & $\mathrm{R}$ & $\mathrm{R}$ Square & $\begin{array}{c}\text { Adjusted R } \\
\text { Square }\end{array}$ & $\begin{array}{c}\text { Std. Error of } \\
\text { the Estimate }\end{array}$ \\
\hline 1 &, $467^{\mathrm{a}}$ &, 218 &, 185 & 8,269 \\
\hline
\end{tabular}

a. Predictors: (Constant), Glb, Gla

b. Dependent Variable: Mo

Analisis Korelasi (r)

Nilai koefisien korelasi (r) antara gaya kepemimpinan instruksi (Gl) dosen dengan motivasi belajar seperti terlihat pada tabel di atas adalah 0,467. Angka ini menunjukkan bahwa terdapat hubungan yang positif dan sangat signifikan antara gaya kepemimpinan instruksi dosen dengan tingkat kematangan $\mathrm{Ml}$ mahasiswa terhadap motivasi belajar mahasiswa. Artinya jika gaya kepemimpinan dosen semakin baik, maka motivai belajar mahasiswa juga akan meningkat.

\section{Analisis Koefisien Determinasi $\left(\mathrm{r}^{2}\right)$}

Nilai koefisien determinasi $\left(\mathrm{r}^{2}\right)$ terlihat pada kolom $\mathrm{R}$ square dalam tabel yaitu 0,218 atau jika dijadikan persen adalah $21,8 \%$. Ini berarti bahwa variabel bebas gaya kepemimpinan instruksi dosen dengan tingkat kematangan Ml mahasiswa secara parsial dapat menjelaskan perubahan variabel terikat motivasi belajar mahasiswa sebesar 21,8\%. Angka tersebut juga dapat diartikan bahwa perubahan gaya kepemimpinan instruksi dosen dengan tingkat kematangan Ml mahasiswa akan memberi kontribusi positif terhadap motivasi belajar mahasiswa, sedangkan $78,2 \%$ lagi dipengaruhi oleh faktor lain yang tidak termasuk dalam perhitungan ini.

ANOVA $^{\text {b }}$

\begin{tabular}{|cl|l|l|l|l|l|}
\hline \multicolumn{1}{|c|}{ Model } & $\begin{array}{c}\text { Sum of } \\
\text { Squares }\end{array}$ & df & Mean Square & F & Sig. \\
\hline 1 & Regression & 894,945 & 2 & 447,472 & 6,544 &, $003^{\mathrm{a}}$ \\
& Residual & 3213,875 & 47 & 68,380 & & \\
& Total & 4108,820 & 49 & & & \\
\hline
\end{tabular}

a. Predictors: (Constant), Glb, Gla

b. Dependent Variable: Mo 


\section{Coefficients $^{\mathrm{a}}$}

\begin{tabular}{|c|c|c|c|c|c|}
\hline \multirow[t]{2}{*}{ Model } & \multicolumn{2}{|c|}{$\begin{array}{l}\text { Unstandardized } \\
\text { Coefficients }\end{array}$} & $\begin{array}{c}\text { Standardized } \\
\text { Coefficients }\end{array}$ & \multirow[t]{2}{*}{$t$} & \multirow[t]{2}{*}{ Sig. } \\
\hline & B & Std. Error & Beta & & \\
\hline (Constant) & 1,436 & 10,781 & &, 133 & 895 \\
\hline Gla & 1,785 & ,497 & ,520 & 3,589 &, 001 \\
\hline Glb & 2,409 & 1,180 & 296 & 2,041 & ,047 \\
\hline
\end{tabular}

a. Dependent Variable: Mo

\section{Uji Hipotesis (Uji-t)}

Dari hasil pengujian hipoteis diperoleh nilai $t$ hitung Gla (kepemimpinan instruksi dengan tugas yang tinggi $=3,589$. Jika dibandingkan dengan nilai t tabel pada level signifikan 5\% $(\alpha=0,05)$ dengan degree of freedom $(\mathrm{df})=47$ adalah 2,02l. Jadi t hitung >t tabel, berarti Ho ditolak dan Ha diterima. Artinya terdapat hubungan yang signifikan antara gaya kepemimpinan instruksi dosen dengan tugas yang tinggi pada tingkat kematangan mahasiswa yang tidak mampu dan tidak mau terhadap motivasi belajar mahasiswa.

Nilai t hitung Glb (kepemimpinan instruksi dengan hubungan yang rendah $=2,041$. Jika dibandingkan dengan nilai $t$ tabel pada level signifikan $5 \%(\alpha=0,05)$ dengan degree of freedom $(\mathrm{df})=47$ adalah 2,021. Jadi t hitung > t tabel, berarti Ho ditolak dan Ha diterima. Artinya terdapat hubungan yang signifikan antara gaya kepemimpinan instruksi dosen dengan hubungan yang rendah pada tingkat kematangan Ml mahasiswa yang tidak mampu dan tidak mau terhadap motivasi belajar mahasiswa.

\section{Analisis Regresi Berganda}

Berdasarkan hasil perhitungan dapat disusun persamaaan regresi seagai berikut:

$Y=1,436+1,785 X_{1}+2,409 X_{2}$

Dari persamaan di atas diketahui konstanta regresi 1,436 , ini berarti pada saat variabel gaya kepemimpinan bernilai 0 , motivasi belajar mahasiswa memiliki nilai 1,436. Sedangkan koefisien regresi variabel Xl (tugas yang tinggi) bernilai positif 1,785 menunjukkan bahwa variabel gaya kepemimpinan instruksi dengan tugas yang tinggi pada tingkat kematangan $\mathrm{Ml}$ mahaiswa berpengaruh positif terhadap motivasi belajar mahasiswa, dimana setiap kenaikan satu satuan variabel kepemimpinan iinstruksi dosen dengan tugas yang tinggi pada tingkat kematangan $\mathrm{Ml}$ mahasiswa akan menaikkan motivasi belajar mahasiswa sebesar 1,785.

Koefisien regresi variabel X2 (hubungan yang rendah) bernilai positif 2,409 menunjukkan bahwa variabel gaya kepemimpinan instruksi 
dengan hubungan yang rendah pada tingkat kematangan Ml mahaiswa berpengaruh positif terhadap motivasi belajar mahasiswa, dimana setiap kenaikan satu satuan variabel kepemimpinan instruksi dosen dengan hubungan yang rendah tingkat kematangan Ml mahasiswa akan menaikkan motivasi belajar mahasiswa sebesar 2,409.

\section{PENUTUP}

\section{Kesimpulan}

Berdasarkan hasil penelitian melalui analisis dan pembahasan dapat disimpulkan bahwa

1. Tingkat kematangan mahasiswa sebagian mampu dan sebagian tidak mampu dalam mengikuti pelajaran dan mengerjakan tugas. Namun hampir semua subjek penelitian adalah tidak punya kemauan atau ragu-ragu dalam mengikuti pelajaran dan mengerjakan tugas. Oleh karena itu gaya kepemimpinan instruksi dan partisipasi dari dosen sangat signifikan dalam meningkatkan motivasi belajar mahasiswa.

2. Hasil penelitian menunjukkan bahwa gaya kepemimpinan dosen berupa delegasi dan konsultasi tidak signifikan dalam meningkatkan motivasi belajar mahasiswa. Hal itu disebabkan oleh tingkat kematangan subjek penelitian belum mencapai kemauan dan keyakinan dalam mengikuti pelajaran dan mengerjakan tugas. Tingkat kematangan mahasiswa seperti ini mungkin karena subjek penelitian masih pada semester 2

3. Oleh karena tingkat kematangan subjek penelitian belum mencapai kemauan dan keyakinan maka perlu diadakan penelitian lanjutan tentang model pembelajaran yang dapat meningkatkan kemauan dan keyakian dalam mengikuti pelajaran, mengerjakan tugas atau dalam hal panggilan. 


\section{KEPUSTAKAAN}

Buku-buku

B. Uno, Hamzah. Teori Motivasi dan Pengukurannya. Gorontalo: Bumi Aksara,2006.

Munandar, Ashar Sunyoto. Psikologi Industri dan Organisasi. Jakarta:UI Devies, 2001.

Purwanto, Ngalim. Psikologi Pendidikan. Jakarta:PT Remaja Rosdakarya, 1990.

Rohman, Arif. Memahami Pendidikan dan Ilmu Pendidikan. Yogyakarta: LaksBang Mediatama Yogyakarta, 2009.

Sardiman. Interaksi dan Motivasi Belajar Mengajar. Jakarta: PT Rajagrafindo, 2007.

Sugihartono, dkk. Psikologi Pendidikan. Yogyakarta: UNY Press, 2007.

Thoha, Mihtah. Kepemimpinan dalam Manajemen. Jakarta:PT Rajagrafindo, 2010.

Internet

"The Hersey-Blanchard Situational Leadership ${ }^{\circledR}$ Theory" diakses pada tanggal 15 Februari 2013; tersedia di

http:/www.mindtools.com/pages/article/newLDR_44.htm 